\title{
Development and Validation of a Body Image Assessment for Patient after Lower Limb Amputation-The Chinese Amputee Body Image Scale-CABIS-
}

\author{
Frank Ho-yin $\mathrm{LAI}^{1}$, Eric $\mathrm{WONG}^{2}$, Simon Kam-man WONG${ }^{1}$, \\ Antonia Ka-wai $\mathrm{SOO}^{1}$, Keith Tsz-fai YIP ${ }^{1}$, \\ Candy Kiu-chor CHAN ${ }^{1}$, Phyllis Lai-chu TSE ${ }^{1}$ \\ ${ }^{1}$ Occupational Therapy Department, Tai Po Hospital, Tai Po \\ ${ }^{2}$ Centre of Epidemiology and Biostatistics, School of Public Health, The Chinese \\ University of Hong Kong
}

\begin{abstract}
Rehabilitation professionals increasingly understand that psychological issue is an important key to achieve rehabilitation goals. Previous studies proved that body image has significant relationship with amputation rehabilitation, however, measurements on body image are not well stated. The aim of this study is to develop a Chinese version of Amputee Body Image Scale (CABIS). In this study, linguistic validity, content validity, test-retest reliability and construct-validity were examined. The 20 items CABIS showed with clear presentation and good content understandability. Expert panel agreed that CABIS covered major constructs in body image for patients after amputation. Moreover, test-retest reliability was found to be $\operatorname{good}(\alpha=.857, p<.01)$. A three-factor structure can be extracted from factor analysis. These three factors were personal factor, social factor and functional factor. Furthermore, the internal consistency of the three individual factors and the overall CABIS were $.852, .826, .636$, and .694 respectively. The moderate internal consistency further confirmed that the items within each factor of the CABIS measure the same construct. Some psychometric properties of CABIS were collected. Further research on criterion-related validity and improvement on factor stability are recommended.
\end{abstract}

Key words: amputation, body image, validation, professional trends

(Asian J Occup Ther 4: 1-11, 2005)

Received: August 19, 2004, Accepted: April 16, 2005 Corresponding to: Frank Ho-yin, Lai; Occupational Therapy Department, Tai Po Hospital, Tai Po, Hong Kong phone: 852-2607-6505 fax: 852-2663-1073 e-mail: laihoyinfrank@yahoo.com, laihyf@sinaman.com

\section{Introduction}

Amputation of a limb may be needed to treat critical ischemia, severe tissue damage due to a trauma, or a life-threatening condition of a limb. Although amputation can be beneficial from a medical point of view, the loss of limb may have a 
considerable impact on patients' health-related quality of life as shown by Van der Schans et al. (2002). As shown by the work of Lerner, Esterhai and Polomano (1993) stated that patients after amputation were "mentally scarred", but it was also reported that these subjects showed only limited restrictions in lifestyle and activity. Smith, Horn and Malchow (1995) investigated a group of unilateral below knee amputees, and found that health-related quality of life in amputees was lower than in age-matched controls for the domains "physical function", "role limitation due to physical problems", and "pain".

Body Image can be defined as the picture that one has in his mind about the appearance (e.g. size and shape) of his body, and the attitude that he forms towards these characteristics of his body. There are two components of body image: the perceptual part (how one sees his own body), and the attitudinal part (how one feels about his perceived bodily appearance) as studied by Drench (1994). A negative body image can be in the form of mild feelings of unattractiveness to extreme obsession with physical appearance that impairs normal functioning as discussed by Rosen, Reiter and Orosan (1995). It is also understandable that body image involves perception, feelings, emotions and physical sensation about one's own body, which were summarized by Parker (1975), Price (1990), Van Deusen (1997), Salter (1988), Miller (1991), Moore \& Malone (1989). Moreover, body image is not static, but ever changing; and is sensitive to changes in mood, environment and life experience as shown by the research works of Schontz (1990), Breakey (1997), Flannery \& Faria (1999), Watanabe, McCluskie and Hakin (1999), Livneh, Antonak \& Gerhart (1990). An important factor in the rehabilitation of amputees that is often overlooked is the individuals' responses to amputation, including the change in body image of amputee patients and the extent to which these changes influence functional outcomes. Assisting amputee to be successfully integrated into community necessitates that body image disturbances associated with amputation be addressed in rehabilitation as summarized by previous research works of Newell (1991),
Schultz, Williamson \& Bridges (1991), Breakey (1997), Mitchell (1997), Crum et al. (1993), The Global Lower Extremity Amputation Study Group (1999), and Whyte \& Niven (2001).

Conventionally, amputation rehabilitation service is mainly physically oriented, as physical assessment and ADL trainings are key components of most programs. Though in recent years, more and more psychological elements are incorporated in the program, i.e. counseling and assessment on psychological readiness of both patients and care-givers, however, the ratio is still comparatively lower than physical elements. In a recent study on effectiveness of a body image on amputation rehabilitation, Hanspal (1998) found that assessment on perceived body image is an essential component for amputation rehabilitation program planning and evaluation.

A valid body image measuring instrument is essential for amputation rehabilitation services. The development and validation of a socioculturally appropriate Chinese Amputee Body Image Scale (CABIS) as shown in Fig. 2 can contribute to enhancement of the existing service standard.

\section{Amputee body image scale}

The Amputee Body Image Scale (ABIS) as shown in Fig. 1, is comprised of 20 items. The ABIS assesses how an amputee perceives and feels about his or her body experience as research works by Breakey (1997). Subjects have to indicate responses to the questions. This scale produces scores that range from 20-100, with high scores indicating high body image disturbance. Three questions (question 3,12 and 16) are reversescored. This type of measurement scale is considered most appropriate to assess the kind of domain-specific concept of self as mentioned by Maurer \& Pierce (1998).

Construct validity was studied by investigating the correlation of the ABIS with other well-known personality scales in the original study. The ABIS showed statistically significant correlation with Index of Self-Esteem (ISE) $(r=.56, p<.01)$; Generalized Contentment Scale (GCS) $(r=.64, p<.01)$; Clinical Anxiety Scale $(r=.57, p<.01)$; Satisfaction with Life Scale 


\section{截肢者身體外型量度表}

\begin{tabular}{|c|c|c|}
\hline 1. & & 我是 位截肢者, 身處在社交場合時, 我會更加放慮我的外表。 \\
\hline 2. & & 我在公罜場合不會穿短褲, 因為免我的義肢外露。 \\
\hline 3. & & 我喜歡自己穿上了義肢後的整體外表。 \\
\hline 4. & & 失去肢體損害了我的身體機能及影響我的日常生活。 \\
\hline 5. & & 我會避免用直身鏡子照鏡，因為我不想看到自己的義肢。 \\
\hline 6. & & 我每天都在复慮白己的外表, 因為我是 -位截肢者。 \\
\hline 7. & & 我感覺到幻肢的存在。 \\
\hline 8. & & $\begin{array}{l}\text { 我感到有別於社會上健全的觀念, 是因為我喪失了肢體, 而且我感至 } \\
\text { 困擾。 }\end{array}$ \\
\hline 9. & & 我覺得我失去保護白己遠離危險的能力, 是因為喪失了肢體。 \\
\hline 10. & & $\begin{array}{l}\text { 我會盡量避免在不穿義肢時到某些地方, 以逃避別人注視的目光。(例 } \\
\text { 如: 辟免到社交地方、在游泳池或沙灘上活動利I作親密的身體接觸。) }\end{array}$ \\
\hline 11. & & 我喪失了肢體, 使我覺得白己擠身於殘障人士之列。 \\
\hline 12. & & 我喜歡不穿義肢時的外表。 \\
\hline 13. & & 當我走路時, 別人會留意著我有破步的步姿。 \\
\hline 14. & & $\begin{array}{l}\text { 我會盡量避免在穿義肢時到某些地方, 以逃避別人汗視的目光。(例 } \\
\text { 如: 避免到社交地方、在游泳池或沙灘上活動和作親密的身體接觸。) } \\
\end{array}$ \\
\hline 15. & & 人們當我足殘障人士看待。 \\
\hline 16. & & 我滿意白己餘肢的外觀。 \\
\hline 17. & & 我會穿寬誒的衣服以遮蓋義肢。 \\
\hline 18. & & 我覺得四肢健全才會有吸引的外表。 \\
\hline 19. & & $\begin{array}{l}\text { 義肢的大小必需要與需要裝 義肢的殘肢相配合, 就如與其它正常肢 } \\
\text { 樣。 }\end{array}$ \\
\hline 20. & & 我不想看到白己的餘肢, 所以我會避免用直身鏡子照鏡。 \\
\hline
\end{tabular}

這份問卷的目的是用來量度你對自己身體外型的看法與感受. 由於這是一份問卷，這 並不是一份測驗, 所以並没有絕對正確或錯誤的答案. 請你仔組和隼確地回答以下每 一項問題, 並把適當數字填在每一項問題旁邊的横線上.

$1=$ 從來沒有, 2 = 甚少有, $3=$ 偶然有, $4=$ 大部份時問有, $5=$ 每一刻都有.

Fig. 2. The Chinese Ampute Body Image Scale (CABIS)

(SWLS) $(r=.58, p<.01)$. The findings supported the interpretation of ABIS as a kind of instrument that measures personal and social related construct.

\section{Methods}

The original English version ABIS was translated into Chinese and backwardly translated by two professional translators respectively. Then, a group of Chinese-speaking people of various educational levels, ranging from primary to tertiary were recruited to complete a questionnaire to assess the linguistic validity of the CABIS. Respondents were required to rate both the degree of "clear presentation" and content "understandability" of the CABIS, which were presented in a 0 to 10 likert scale by the use of a questionnaire. The mean scores of each question were calculated, and 8.0 was selected as the cut-off score of a clear presentation and good content understandability. Comments from respondents 


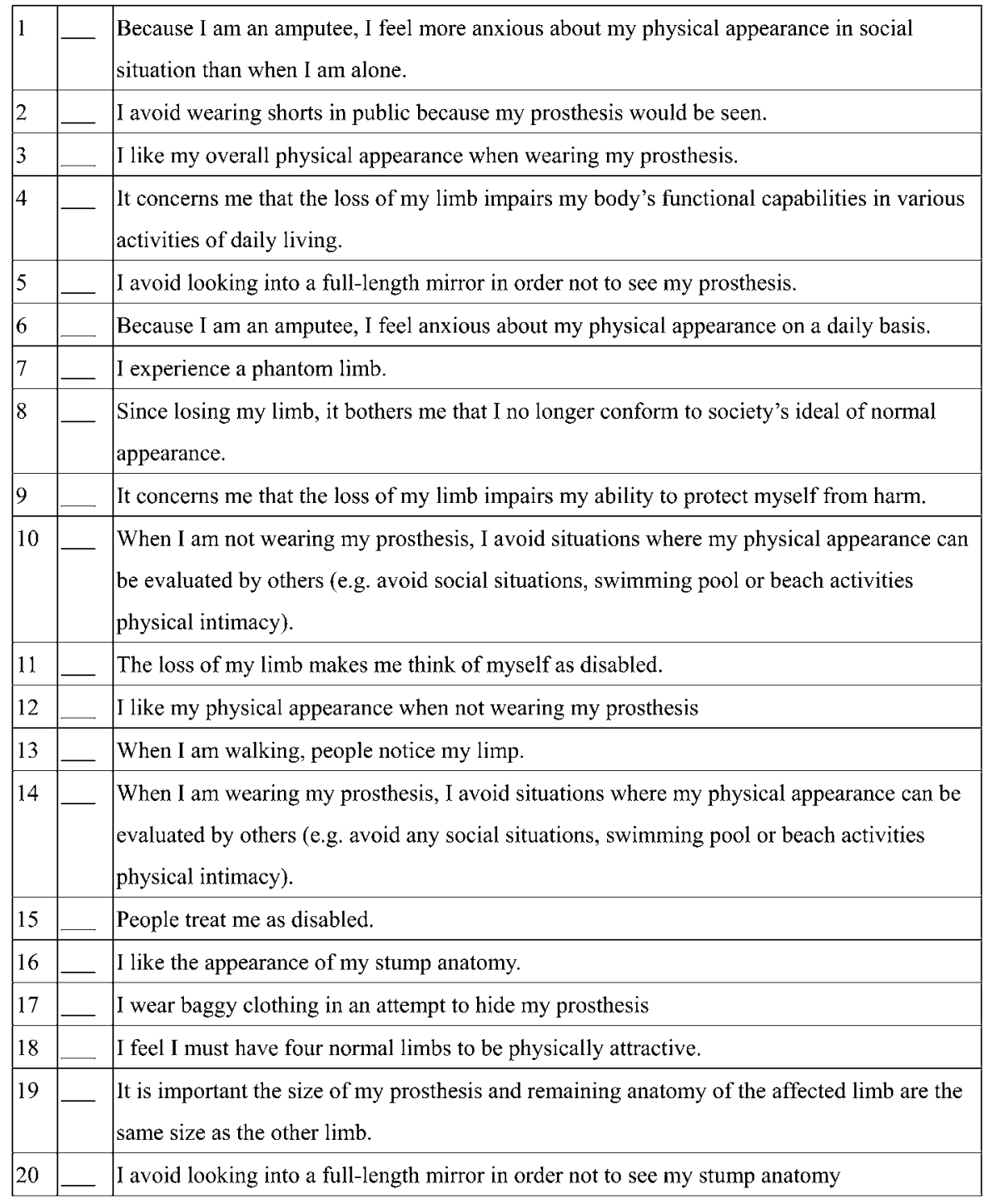

Fig. 1. The original Amputee Body Image Scale (ABIS)

The questionnaire is designed to measure how you see and feel about your body image. It is not a test so there are no right or wrong answers. Please answer each item as carefully and as accurately as you can by placing the appropriate number inside each questions as follows.

$1=$ None of time, $2=$ Rarely, $3=$ Some of the time, $4=$ Most of the time, $5=$ All of the time

were critically reviewed and questions were modified in syntactical or structural aspects.

Then, a group of bilingual expert panels whom should have at least 5 years of working experience in amputation rehabilitation were invited to complete a questionnaire, which aimed at evaluating both face and content validity of the CABIS. The questionnaire was designed to study the adequacy, accuracy and ease of understanding of translation, face and content validity of the 
CABIS. This questionnaire will be sent together with a covering letter and both CABIS and ABIS for reference. Panel members were invited to judge whether they agreed the translation of each question was accurate or not, by choosing "Agree" or "Disagree". Qualitative comments for modification of translation were also requested if "Disagree" was rated for that item. The percentage of agreement in each question was calculated, and $85 \%$ agree was selected as the cutoff score for accurate translation. Comments from all panels were critically reviewed and descriptive statistics such as percentage of experts' agreement on the accuracy of translation was also analyzed. Basing on the evaluation by the expert panels, professional translators then further modified and finalized the CABIS.

For test-retest reliability, a group of amputated patients would be recruited. Selection criteria should be below-knee amputated patients aged from 18 to 65 , and average time after amputation should be within two months, should have no previous major trauma history, and without mental function deficiency. They were asked to complete the CABIS on the day after admission and two days after their admission. Such a short interval can ensure there would be no significant difference in their perceived body image. The reliability of the CABIS is determined by intraclass correlation coefficient (ICC) and analyzed by the model of one way random. Through power analysis and effect size estimation, 50 subjects were required. And for further factor structure estimation, sample size of 50 was marginally satisfactory in factor analysis by principal component analysis for construct validation.

\section{Results}

\section{Linguistic validity}

Twenty Chinese-speaking respondents completed the linguistic validity questionnaire, which aimed at determining both the degree of

Table 1. Mean scores of linguistic validity of the 20 items of the CABIS

\begin{tabular}{cccc}
\hline Item No. & Clear Presentation & Understandability & Relevancy to Concept \\
\hline 1 & $* 7.85$ & $* 7.77$ & $* 7.08$ \\
2 & $* 7.68$ & $* 7.58$ & 8.78 \\
3 & $* 7.58$ & $* 7.07$ & 8.90 \\
4 & 8.47 & 8.53 & 8.67 \\
5 & 8.47 & 8.53 & 8.13 \\
6 & 8.02 & 8.35 & 7.83 \\
7 & $* 6.90$ & $* 6.88$ & 8.23 \\
8 & $* 6.95$ & $* 6.85$ & $* 6.96$ \\
9 & 8.73 & 8.07 & 8.93 \\
10 & 8.42 & 8.88 & 8.70 \\
11 & 8.97 & 8.77 & 8.42 \\
12 & $* 7.30$ & $* 7.32$ & 8.17 \\
13 & 8.18 & 8.15 & 8.05 \\
14 & 9.00 & 8.85 & 8.92 \\
15 & 8.75 & 8.22 & 8.43 \\
16 & $* 7.68$ & $* 7.68$ & 8.45 \\
17 & 8.32 & 8.13 & 8.07 \\
18 & 8.92 & 8.77 & 7.10 \\
19 & $* 7.17$ & $* 7.90$ & $* 7.72$ \\
20 & $* 7.93$ & $* 7.92$ & $* 7.60$ \\
\hline
\end{tabular}

*: Mean value of clear presentation and understandability below the cut-off score of 8.00, and items required refinement to enhance questions' clear presentation and understandability. 
Table 2. Percentage of agreement by panel expert in the translation of 20 items of the CABIS

\begin{tabular}{cccc}
\hline Item No. & $\begin{array}{c}\text { Agree (number } \\
\text { of panel member) }\end{array}$ & $\begin{array}{c}\text { Disagree (number } \\
\text { of panel member) }\end{array}$ & \% of Agreement \\
\hline 1 & 7 & 0 & 100 \\
2 & 6 & 1 & 85.7 \\
3 & 6 & 1 & 85.7 \\
4 & 7 & 0 & 100 \\
5 & 6 & 1 & 85.7 \\
6 & 6 & 2 & 85.7 \\
$* 7$ & 5 & 1 & 71.4 \\
8 & 6 & 2 & 85.7 \\
$* 9$ & 5 & 1 & 71.4 \\
10 & 6 & 0 & 85.7 \\
11 & 7 & 2 & 100 \\
$* 12$ & 5 & 1 & 71.4 \\
13 & 6 & 0 & 85.7 \\
14 & 7 & 0 & 100 \\
15 & 7 & 2 & 100 \\
$* 16$ & 5 & 2 & 71.4 \\
$* 17$ & 5 & 0 & 71.4 \\
18 & 7 & 1 & 85.7 \\
19 & 6 & 1 & 85.7 \\
20 & 6 & & 00 \\
\hline
\end{tabular}

*: level of agreement in accurate translation below $85 \%$ of agreement, and these items need further modification by professional translator.

clear presentation and content understandability of the CABIS. A stringent mean score of 8.0 was selected as the cut-off score of a clear presentation and good content understandability. The results were summarized in Table 1, 9 questions in the CABIS (1, 2, 3, 7, 8, 12, 16, 19 and 20) showed with mean score of clear presentation and understandability below the cut-off score, which required refinement to enhance questions' clear presentation and understandability.

After those questions were linguistically refined by the translator, all 7 expert panels (4 were male and 3 were female; including 4 occupational therapists, 2 physiotherapists and 1 nurse working in a rehabilitation hospital) agreed the modification can increase the degree of clarity, comprehensiveness, and comprehensibility of the CABIS.

\section{Content validity}

Table 2 showed the level of agreement of the panel members on the translation of items of the CABIS , with ranged from $71.4 \%$ to $100 \%$. As $85 \%$ agree was selected as the cut-off score for accurate translation, 5 questions (question 7, 9, 12, 16 and 17 ) with only $71.4 \%$ agreement in the CABIS were considered as not accurate enough, and needed to be further modified by professional translator.

For content relevancy, CABIS was evaluated to see whether the questions were relevant to body image for patients after amputation. As summarized in Table 3, results showed that panel members agreed that all items were relevant to the content area. The percentage of agreement ranged from $85.7 \%$ to $100 \%$, and the median scores were ranged from 4 to 5 in the items. The 20 items in the CABIS can be regarded as good items. The content representativeness of the CABIS was 
Table 3. Results of content relevancy of the CABIS

\begin{tabular}{|c|c|c|c|c|}
\hline \multirow[b]{2}{*}{ Item } & \multicolumn{3}{|c|}{$\%$ of Agreement } & \multirow[b]{2}{*}{ Measurement Median" } \\
\hline & Agree & Neutral & Disagree & \\
\hline 1 & 100 & 0 & 0 & 4.5 \\
\hline 2 & 100 & 0 & 0 & 4.5 \\
\hline 3 & 100 & 0 & 0 & 4.5 \\
\hline 4 & 100 & 0 & 0 & 4 \\
\hline 5 & 85.7 & 14.3 & 0 & 4 \\
\hline 6 & 85.7 & 14.3 & 0 & 4.5 \\
\hline 7 & 85.7 & 14.3 & 0 & 4.5 \\
\hline 8 & 85.7 & 14.3 & 0 & 4 \\
\hline 9 & 100 & 0 & 0 & 4.5 \\
\hline 10 & 85.7 & 14.3 & 0 & 4.5 \\
\hline 11 & 85.7 & 14.3 & 0 & 4 \\
\hline 12 & 100 & 0 & 0 & 4.5 \\
\hline 13 & 100 & 0 & 0 & 4.5 \\
\hline 14 & 100 & 0 & 0 & 5 \\
\hline 15 & 100 & 0 & 0 & 5 \\
\hline 16 & 100 & 0 & 0 & 5 \\
\hline 17 & 100 & 0 & 0 & 4 \\
\hline 18 & 85.7 & 0 & 14.3 & 4 \\
\hline 19 & 100 & 0 & 0 & 4 \\
\hline 20 & 100 & 0 & 0 & 4 \\
\hline
\end{tabular}

*: Degree of clear presentation and content understandability of the CABIS.

Table 4. Results of content representativeness of the CABIS

\begin{tabular}{ccccc}
\hline & \multicolumn{3}{c}{$\%$ of Agreement } \\
\cline { 2 - 4 } Items $1-20$ & Agree & Neutral & Disagree & Median \\
\hline
\end{tabular}

$100 \%$ agreement was achieved in the content representativeness of the CABIS.

examined in terms of the 20 items as a whole to the measurement of body image for patients after amputation. The result was summarized in Table 4. The percentage of agreement was $100 \%$ and median score was 4 , which indicated all panel members agreed that these 20 items cover the major constructs and could represent a person's perception on body image.

\section{Test-retest reliability}

In testing for the test-retest reliability, a group of 50 subjects (40 male and 10 female) were recruited by convenient sampling. Their age ranged from 35-75 (with mean age 62.3). All were below-knee-amputated patients, and the time from amputation to first interview ranged from 1.32 to 1.48 months (with mean 1.42 months). They were asked to complete the CABIS on the day after admission (pre-data) and two days after their admission (post-data), and these pre-and-post CABIS data were collected for reliability testing. Reliability of the CABIS was determined by IntraClass Correlation coefficient (ICC) and analyzed by the model of one way random. After statistically operation by SPSS 10.0, the test-retest reliability coefficient of CABIS was .857 . 
Table 5. Initial statistics for each factor of CABIS

\begin{tabular}{rrrrrr}
\hline Items & Communality & Factor & Eigenvalue & \% of Variance & Cumulative \% \\
\hline 1 & .580 & 1 & 7.424 & 37.119 & 37.119 \\
2 & .384 & 2 & 2.197 & 13.985 & 51.104 \\
3 & .404 & 3 & 1.330 & 9.153 & 60.257 \\
4 & .541 & 4 & .989 & 4.255 & 64.512 \\
5 & .500 & 5 & .949 & 4.143 & 68.655 \\
6 & .500 & 6 & .829 & 4.120 & 72.775 \\
7 & .289 & 7 & .714 & 3.569 & 73.344 \\
8 & .393 & 8 & .673 & 3.365 & 79.709 \\
9 & .555 & 9 & .621 & 2.584 & 82.293 \\
10 & .561 & 10 & .562 & 2.808 & 85.101 \\
11 & .392 & 11 & .552 & 2.262 & 87.361 \\
12 & .624 & 12 & .452 & 2.111 & 89.472 \\
13 & .515 & 13 & .422 & 1.929 & 91.401 \\
14 & .636 & 14 & .386 & 1.800 & 93.201 \\
15 & .485 & 15 & .360 & 1.640 & 94.841 \\
16 & .712 & 16 & .328 & 1.531 & 96.481 \\
17 & .652 & 17 & .306 & 1.261 & 97.742 \\
18 & .309 & 18 & .252 & 1.084 & 98.826 \\
19 & .647 & 19 & .217 & 1.023 & 99.849 \\
20 & .477 & 20 & .175 & .151 & 100.000 \\
\hline
\end{tabular}

3 factor structure was shown to have optimal eigenvalue, $\%$ of variance and cumulative $\%$

Bartlett's test of sphericity: $925.18(\mathrm{p}=.000)$.

Kaiser-Meyer-Olkin Measure of Sampling Adequacy: .735.

Extraction method: Principal component analysis.

\section{Factor analysis and construct validity}

Factor structure of CABIS was examined by factor analysis. The result of the Bartlett's test of sphericity was $925.18(p<.000)$, and the value of the Kaiser-Meyer-Olkin Measure of Sampling Adequacy was .735. The Bartlett's test of spherically can be used to test the hypothesis that the correlation matrix is an identity matrix. That is, all diagonal terms are 1 and all off-diagonal terms are 0 . The current study obtained a value of 925.18 for the test of sphericity. Since the value is large and the associated significance level of 0.000 is small, it is unlikely that the population correlation matrix is an identity. If the hypothesis that the population correlation matrix is an identity cannot be rejected because the observed significance level is large, one should reconsider the use of the factor model (Norussis (1985)). The good Kaiser-Meyer-Olkin value obtained and the highly significant level of the test of sphericity, were both very comfortable indications that the given set of data were adequate for factor analysis.

These good values supported further application of factor analysis to explore the latent structure of the CABIS. Principal component analysis method of factor extraction was used in this study. Table 5 reported the statistics of principal component analysis. In the initial analysis, a total of three factors could be extracted with the eigenvalue greater than 1.00. In terms of total variance, the three factors accounted for $60.26 \%$ of total variance, which can be considered as a reasonable factor number. Furthermore, the scree plot in Fig. 3 showed that the curve straightened out at the three factors. Therefore, the fitness of three-factor solution could be identified.

In the rotation phase of factor analysis, it aimed at achieving simpler and theoretically more meaningful factor solutions. Oblimin rotation was employed in further investigating the factor 
Scree Plot

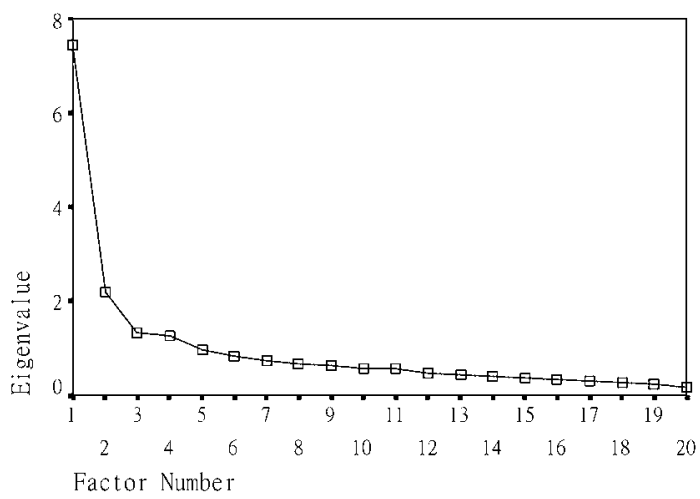

Fig. 3. Scree plot of the factors of the CABIS

The graph for the scree test is presented in Fig. 3. The scree diagram of the factors of the CABIS justifies the three-factor solution to the data. 3-factor structure was shown to have optimal eigenvalue as shown in this scree plot.

loadings. The result was summarized in Table 6 . The three factors were labeled according to the items' nature of construct. Factor 1 was personal factor; factor 2 was social factor; and factor 3 was functional factor. The value of factor loadings was the criteria to group the items in different factors respectively. Personal domain included 9 questions, i.e. question $3,5,6,7,12,16,17,18$ and 20 (e.g. question 3: I like my overall physical appearance when wearing my prosthesis). Social domain included 7 questions, i.e. question 1,2,8,10,11,14 and 15 (e.g. question 1: Because I am an amputee, I feel more anxious about my physical appearance in social situation than when I am alone). Functional domain included 4 questions, i.e. question 4,9,13 and 19 (e.g. question 4: It concerns my that the loss of my limb impairs my body's functional capabilities in various activities of daily living).

The relationships of these three factors were examined in terms of item description, internal consistency and correlation. Cronbach's alpha was used to measure the internal consistency of the CABIS. In these three factors, the ranges of itemtotal correlation were .556 to $.786, .348$ to .653 , and .482 to .658 respectively. They indicated a fair relationship of the questions to their respective
Table 6. Factor loadings of items of the CABIS after oblimin rotation

\begin{tabular}{|c|c|c|c|}
\hline Items & Factor 1 & Factor 2 & Factor 3 \\
\hline 5 & .908 & & \\
\hline 6 & .828 & & \\
\hline 3 & .815 & & \\
\hline 12 & .697 & & \\
\hline 20 & .642 & & \\
\hline 7 & .628 & & \\
\hline 17 & .586 & & \\
\hline 18 & .579 & & \\
\hline 16 & .500 & & \\
\hline 14 & & .836 & \\
\hline 8 & & .779 & \\
\hline 2 & & .751 & \\
\hline 1 & & .701 & \\
\hline 10 & & .610 & .467 \\
\hline 11 & & .541 & \\
\hline 15 & & .505 & .358 \\
\hline 4 & & & .625 \\
\hline 9 & & & \begin{tabular}{|l|}
.619 \\
\end{tabular} \\
\hline 19 & & & \begin{tabular}{|l|}
.599 \\
\end{tabular} \\
\hline 13 & & & \begin{tabular}{|l|}
.395 \\
\end{tabular} \\
\hline
\end{tabular}

Note. Extraction method: Principal component analysis. Rotation method: oblimin rotation.

Remark: Only showed factor loadings above .35

factors. The internal consistency of the three individual factors and the overall CABIS were found to be $.852, .826, .636$, and .694 respectively as shown in Table 7. The moderate internal consistency implied that the questions within each factor and the factors of the CABIS measured the same construct. Pearson correlation coefficients among the three factors were presented. As shown in Table 8, all factors were found to have good correlation with one another (ranged from $r=532$, $p<.000$ to $r=.652, p<.000$ ). The factor 1 "Personal factor" and factor 2 "Social Domain" had the highest relationship $(r=.652, p<.000)$. The 
Table 7. Internal consistency of factors in CABIS

\begin{tabular}{lcc}
\hline & $\begin{array}{c}\text { Cronbach's } \\
\text { Alpha }\end{array}$ & $\begin{array}{c}\text { Alpha of CABIS } \\
\text { if deleted }\end{array}$ \\
\hline Factor 1-Personal Factor & .852 & .432 \\
Factor 2-Social Factor & .826 & .597 \\
Factor 3-Functional Factor & .636 & .623 \\
Overall CABIS & .694 & \\
\hline
\end{tabular}

Table 8. Correlations among factors in CABIS

\begin{tabular}{lccc}
\hline & $\begin{array}{c}\text { Personal } \\
\text { Factor }\end{array}$ & $\begin{array}{c}\text { Social } \\
\text { Factor }\end{array}$ & $\begin{array}{c}\text { Functional } \\
\text { Factor }\end{array}$ \\
\hline Personal Factor & - & $\begin{array}{c}r=.652 \\
p<.01\end{array}$ & $\begin{array}{c}r=.532 \\
p=<.01\end{array}$ \\
\hline Social Factor & - & $\begin{array}{c}r=.545 \\
p<.01\end{array}$ \\
\hline Functional Factor & & & -
\end{tabular}

reliability coefficients of ICC among three factors were $.914, .900$ and .800 as shown in Table 9, which was good and adequate evidence to substantiate the use of CABIS across different time.

\section{Discussion}

In this study, a number of modifications were made to questions in CABIS. The reasons for the necessity in modification of questions could be broadly classified into 5 categories: 1) use of specific terms in body image measures; 2) use of generic terms was difficult in psychosocial measurement of Chinese patients; 3 ) inaccurate translation from English to Chinese version; 4) sensation structure difference between ABIS and CABIS; 5) clarification of meaning in psychosocial construct and 6) grammatical reason in understanding.

When validating the ABIS to CABIS, factor structure between "Personal" and "Social" factors of CABIS might be different from the original study. It was possibly due to cultural difference between Western and Chinese, which created a different point of view on perceived body image.
Table 9. Reliability coefficient of factors in CABIS

\begin{tabular}{lc}
\hline & Reliability Coefficient \\
\hline Factor 1-Personal Factor & .914 \\
Factor 2-Social Factor & .900 \\
Factor 3-Functional Factor & .800 \\
Overall CABIS & .857 \\
\hline
\end{tabular}

For example, the importance of social importance would be much more important than personal acceptance, potential overall estimation on the difficulty in social acceptance, personal characteristics such as acceptance in newly acquired body image and believe in fate and natural arrangements are often the Chinese patients' concern rather than outcomes. Moreover, Chinese patients showed more concern over the "functional" aspect rather than "personal" importance after amputation was also a major factor for further consideration.

Further validation work was recommended to incorporate more "functional" related questions, to correlate if functional improvement could substantially improve body image and to crossvalidate with other psychosocial instrument or quality of life measures for patients after amputation.

\section{Conclusion}

The CABIS was developed to assess a person's perceived body image. The content relevancy and representativeness had been investigated with a high level of agreement. The test-retest reliability was estimated to be good in terms of ICC. The construct validity was analyzed by factor analysis. A three-factor structure was extracted. The factor loading of items was ranged from .395 to .908 . The names of three factors were personal factor, social factor and functional factor. A moderate internal consistency was found between items, and the correlations between factors were considerably to be good. A confirmatory factor analysis across different subject groups was recommended in further study to increase the clinical utilities of CABIS. 


\section{References}

Breakey, J. (1997). Body Image: The lower-limb amputee. J. Prosthe. Orthotics, 9(2), 58-66.

Crum, R.M., Anthony, J.C., Bassett, S.S., \& Folstein, M.F. (1993). Population-based norms for the mini-mental state examination by age and education level. J. Am. Med. Assoc., 269(10), 2386-2391.

Drench, M. (1994). Changes in body image secondary to disease and injury. Rehab. Nursing, 19, 31-36.

Flannery, J.C., \& Faria, S.H. (1999). Limb loss: alterations in body image. Journal of Vascular Nursing, 17(4): 100-106; quiz 107-108.

Hanspal, M. (1998). Body image and patients with amputations: does the prosthesis maintain the balance? International Journal of Rehabilitation Research, 21, 355-363.

Lerner, R.K., Esterhai, J.L., \& Polomano, R.C. (1993). Quality of life assessment of patients with posttraumatic fracture nonunion, chronic refractory osteomyelitism and lower extremity amputation. Clinical Orthopaedics, 295, 28-36.

Livneh, H., Antonak, R.F., \& Gerhart, J. (1999). Psychosocial adaptation to amputation: the role of sociodemographic variables, disability-related, factors and coping strategies. International Journal of Research, 22, 21-31.

Maurer, T.J., \& Pierce, H.R. (1998). A comparison of likert scale and traditional measures of selfefficacy. Journal of Applied Psychology, 83, 324329.

Miller, K. (1991). Body-image therapy. Nursing Clinics of North America, 26(3), 727-736.

Mitchell, A. (1997). Body Scheme Theory. Physical and Occupational Therapy in Paediatrics, 17, 523.

Moore, W.S., \& Malone, J.M. (1989). Lower extremity amputation. Philadephia: W.B. Saunders.

Newell, R. (1991). Body image disturbance; cognitive behavioural formulation and intervention. Journal of Advanced Nursing, 16 (12), 1400-1405.

Norussis, M. J. (1985). SPSS-X advanced statistics guide. New York: McGraw Hill.
Parker, C.M. (1975) Psycho-social transitions: comparisons to loss of a limb and loss of a spouse. British Journal of Psychology, 127, 204-210.

Price, B. (1990). A model of body image care. Journal of Advanced Nursing, 15(5), 585-593.

Rosen, J.C., Reiter, J., \& Orosan, P. (1995). Cognitive-behavioral body image therapy for body dysmorphic disorder. Journal of Consulting \& Clinical Psychology, 63(2), 263-269.

Salter, M. (1988). Altered body image. John Wiley.

Schultz, R., Williamson, G.M., \& Bridges, M. (1991). Limb amputation among the elderly: psychosocial factors influenzing adjustment. Washington D.C.: AARP Andrus Foundation.

Shontz, F.C. (1990). Body image and physical disability . Cash, T.F., \& Pruzinsky, T. (eds.), Body images: development, deviance and change. New York: Guilford.

Smith, D.G., Horn, P., \& Malchow, D. (1995). Prosthetic history, prosthetic charges, and functional outcome of the isolated, traumatic below-knee amputee. Journal of Trauma, 38, 4447.

The Global Lower Extremity Amputation Study Group (1999). Epidemiology of lower extremity amputation in centers in Europe, North America and East Asia. British Journal of Surgery, 87(3), 328-337.

Van der Schans, C.P., Geertzen, J.H.K., Schoppen, T., \& Dijkstra, P.U. (2002). Phantom pain and health-related quality of life in lower limb amputees. Journal of Pain and Symptom Management. 24(4), 429-436.

Van Deusen, A.J. (1997). Body image of non-clinical and clinical population of men: a literature review. Occupational Therapy in Mental Health, 13, 3755.

Watanabe, Y., McCluskie, P.J., Hakin, E. Asami, T., \& Watanabe, H. (1999). Lower limb amputee patients' satisfaction with information and rehabilitation. International Journal of Rehabilitation Research, 22, 67-69.

Whyte, A.S., \& Niven, C.A. (2001). Psychological distress in amputees with phantom limb pain. Journal of Pain and Symptom Management, 22(5), 938-946. 